\title{
Influence of Organisational Culture on Decision Making in Select Public Sector Enterprises
}

Madhumita Chatterji $^{*}$ and M H Sharieff ${ }^{\dagger}$

\section{Abstract}

Public sector Enterprises in India, particularly the Central Government owned were designated as "Temples of Modern India" by Pandit Jawaharlal Nehru, the first prime Minister of India. They were started with clear aim of providing employment, and supplying goods at affordable prices besides the larger goal of industrialization and balanced growth. It did serve the purpose till liberalization was initiated in 1990. The globalization and liberalization brought about extreme pressure on hitherto protected industries to take on competition. The culture developed over five decades was precipitously called upon to take on the changes that were taking place in the environment forcing many PSEs to turn red unable to deal with competition. This study attempts to understand the organisational culture that was developed over a period of 50 years and its ability to cope with changes through effective and efficient decision making by executives and by their leadership or management style and to a certain extent the presence of unique PSE ecosystem. It is being explored that notwithstanding the individual differences in decision making, organisational culture forces all executives to

* Director \& Dean (Academics), IFIM Business School, Bangalore, Karnataka, India;

† Research Scholar, IFIM Research Centre, Visveswaraya Technological University(VTU), Belgaum, India; mhsharieff@consultant.com 
adopt the dominant decision making style mediated by management styles. This study is empirical with crosssectional design, using convenience sampling technique and a self-administered questionnaire.

Keywords: Confirmatory factor analysis, statistical results, research methods, structural equation modelling, SEM Model, Model fit, organisational culture, decision making, management style

\section{Introduction}

Several researchers have attempted to measure organisational culture. The research intensity in the last 15 years is heavily concentrated on study of organisational culture in private sectors as there has been continuous decline in public sector organisation in most of the developed world. The free market economy emphasis has forced many developed and developing countries to resort to disinvestment in public owned enterprises. Accordingly, the interest of the researchers in western world is limited as far as organisational studies involving public sector manufacturing units are concerned; however most of the studies are related to organisations involved in public services. In India not many studies were conducted to study organisational culture. Some of the studies conducted in India are; "A study of HRM practices and organisational culture in selected private sector organisations in India", ( Singh, 2009), "A study on organisational culture with reference to Sail, Salem", (Elangovan \& Jayashree, 2013), "Effect of organisational culture on employee commitment in the Indian IT services sourcing industry", (Wolfgangmessner, 2013),"The relationship of organisational culture with productivity and quality: a study of Indian software organisations"(Mathew, 2007), "Examining the relationship between organisational culture and leadership styles",(Sanjeev et al., 2009), "Influence of organisational climate and organisational culture on managerial effectiveness: an inquisitive study" (Amjad Ali \& Patnaik, 2014) etc. It may be noted that all except one is in public sector. None has covered public sector units in fair detail. 


\section{Organisational culture}

As with many management concepts, there is no common agreed upon definition among social scientists or management experts for the term "culture". The terms "organisational culture" and "corporate culture" are used interchangeably. Most writers refer to organisational culture as this is considered to be a more inclusive term referring to the culture of not-for-profit organisations as well as business enterprises or corporations. Edgar Henry Schein, the most quoted writer has summed up culture as a sort of evolutionary social mechanism discovered, developed and adopted by a social group within organisations to manage internal integration issues and external pressures for survival. If such mechanism becomes successful, it is perpetuated through socialization to other new members entering organisation and it becomes a norm.

Typologies are used as metaphors and have been mainly utilized in studies of organisational culture (OC) for their ability to communicate easily a sense of what the culture is. Table 1 outlines various typologies employed by notable researchers. Cameron and Quinn (1999) emphasized that there is no one "correct" typology for an organisation. Scott et al. have also recognized that there is no ideal instrument as each tool has limitations for use or scope.

Table 1: Typology of organisational cultures:

\begin{tabular}{|c|c|c|c|c|c|c|}
\hline $\begin{array}{l}\text { Harrison } \\
\text { in Graves, } \\
1986 \text { ) }\end{array}$ & $\begin{array}{l}\text { Quinn } \\
\text { (1988) }\end{array}$ & $\begin{array}{l}\text { Handy } \\
\text { (1993: } \\
\text { 1995) }\end{array}$ & $\begin{array}{l}\text { Hofstede } \\
\text { (1997) }\end{array}$ & $\begin{array}{l}\text { McNamara, } \\
\text { 2000) }\end{array}$ & $\begin{array}{l}\text { Trompe } \\
\text { naars } \\
\text { and } \\
\text { Hampden- } \\
\text { Turner } \\
\text { (1999) }\end{array}$ & $\begin{array}{l}\text { Schneider } \\
\text { (2000) }\end{array}$ \\
\hline $\begin{array}{l}\text { Power } \\
\text { Role } \\
\text { Task } \\
\text { Atomistic }\end{array}$ & $\begin{array}{l}\text { Clan } \\
\text { Hierarchy } \\
\text { Market } \\
\text { Adhocracy }\end{array}$ & $\begin{array}{l}\text { Club } \\
\text { Role } \\
\text { Task } \\
\text { Person }\end{array}$ & $\begin{array}{l}\text { Families } \\
\text { Pyramids } \\
\text { Markets } \\
\text { Machines }\end{array}$ & $\begin{array}{l}\text { Club } \\
\text { Fortress } \\
\text { Academy } \\
\text { Baseball } \\
\text { team }\end{array}$ & $\begin{array}{l}\text { Family } \\
\text { Eiffel } \\
\text { tower } \\
\text { Market } \\
\text { Adhocracy }\end{array}$ & $\begin{array}{l}\text { Control } \\
\text { Collabo- } \\
\text { ration } \\
\text { Compe- } \\
\text { tence } \\
\text { Cultiva- } \\
\text { tion }\end{array}$ \\
\hline
\end{tabular}

Compiled by Researcher

Researchers have proposed various methods for measuring and analysing organisational culture, which include holistic studies 
(ethnographic analyses), semiotic studies (language and symbolism focus) as well as quantitative studies (questionnaire approach) (Ouchi \& Wilkins, 1985). A number of studies to measure organisational culture have been successfully conducted. These include studies utilizing qualitative and quantitative techniques as well as a combination of both (Hofstede, 1991; Parker, 2000). This study is to discover the influence of organisational culture on decision making. The link between culture and decision is aptly stated by Blenko et al. The manner in which managers in a company behave while making decisions is an important feature of the organisation's culture and it can profoundly affect performance. Decisions are what matter in an organisation as people and processes are evaluated on the basis of their contribution to effective and efficient decision making and its execution. (Blenko et al. 2011).All these decisions tend to be vastly different from function to function, however many theorists have argued that individuals have habitual tendencies to approach various problems in consistently similar ways, intuition use or analytical decision making (Dane \& Pratt, 2009); The foundational decision-making styles work in professional decision making and individuals also attempt to develop a comprehensive set of decision-making styles or typical approach to decision making. Furthermore, these decision-making tendencies, commonly referred to as decisionmaking styles, constitute an individual difference that varies between people( Jepsen \& Dilley, 1974; Scott \& Bruce, 1995).

In this study, management style is used as an intervening variable. Four management styles or leadership styles suggested by Hersey Blanchard were also measured. However, this paper discusses only one construct -organisational culture, its sub-constructs and its direct and indirect relationship with decision making. All variables of the study are given in table 2 . 
Table 2: Variables of the study

\begin{tabular}{|c|c|c|c|c|}
\hline $\begin{array}{c}\text { Dependent } \\
\text { Variables }\end{array}$ & $\begin{array}{c}\text { Independent } \\
\text { Variables }\end{array}$ & $\begin{array}{c}\text { Intervening } \\
\text { Variables }\end{array}$ & \multicolumn{2}{|c|}{$\begin{array}{c}\text { Moderator } \\
\text { Variables }\end{array}$} \\
\hline \multicolumn{5}{|c|}{ Defined variable of study } \\
\hline $\begin{array}{c}\text { Decision } \\
\text { Making } \\
\text { Style }\end{array}$ & $\begin{array}{c}\text { Construct } \\
\text { Organisation } \\
\text { Culture }\end{array}$ & $\begin{array}{l}\text { Management } \\
\text { Style }\end{array}$ & $\begin{array}{c}\text { Decision } \\
\text { Model } \\
\text { prevalent }\end{array}$ & $\begin{array}{c}\text { Eco- } \\
\text { System }\end{array}$ \\
\hline & $\begin{array}{l}\text { Sub-Construct } \\
\text { Latent variable }\end{array}$ & & & \\
\hline & $\begin{array}{l}\text { A: Clan } \\
\text { B:Market } \\
\text { C:Adhocracy } \\
\text { D: Hierarchy }\end{array}$ & & & \\
\hline & $\begin{array}{l}\text { Instrument used: } \\
\text { OCAI- } \\
\text { questionnaire } \\
\text { developed by } \\
\text { Cameron/ } \\
\text { Quinn } 2000 \text { and } \\
\text { modified } \\
\text { for this study }\end{array}$ & & & \\
\hline
\end{tabular}

Method: This research uses empirical study using standard questionnaires developed by researchers who had studied organisational culture, decision making style and leadership or management styles. These inventories were modified after pilot test to suit Indian respondent's requirement, without much loss of any of the basic objectives of original designers of these scales. Two other inventories -Decision Model prevalent or opted in organisations and Ecosystem were developed independently based on extensive literature research and discussion with PSE senior executives to identify valid indicators. Exploratory factor analysis and confirmatory factor analysis were conducted with sample data to confirm their validity and reliability along with standard instruments of other researchers used in this empirical study. The sampling techniques and sample size selected were, keeping in view the researchers' suggestions in earlier studies for undertaking structural equation modeling (SEM). There is considerable debate on what should be the size of sample for meaningful analysis and 
inference. According to Sivo et al. (2006) there is little agreement among researchers on the recommended sample size for SEM. On the other side Garver and Mentzer (1999) and Hoelter (1983) recommended a 'critical' sample size of 200. Similarly Boomsma (1983) suggested samples of 200 or more. Gerbing and Anderson (1985), found the added benefit that with three or more indicators per factor, a sample size of 100 will usually be sufficient for convergence, and a sample size of 150 will generally sufficient for a convergent and proper solution. As per Kline (2005), a general rule of thumb is that the minimum sample size should be not less than 200 or 5-20 times the number of parameters to be estimated, whichever is larger? Thus, the sample of more than 200 responses is considered sufficient to undertake SEM. The cross-sectional data was obtained adopting convenience sampling from several sampling units involved in metal manufacturing activity; they are PSU divisions or functional departments across India. The questionnaires were self-administered to Chief Managers or others with different designations but currently working in grade or level VI, with minimum of 5 years in service in the current organisation either promoted or directly appointed; who act as functional head or area head with decision making authority. For precision in sample size determination 95 percent confidence level was used. Where the size of interval estimate is large, the possibility of dispersion of the population is smaller with no finite population, adjustment using correction factor is required.

Results: The analysis of sample data confirmed some of the proposed structured theory and revealed relationship between constructs. Important aspect measured in the organisational culture (OC) constructs revealed that in the model there is issue with clan culture in PSEs. The relationship to decision making was insignificant and that some of the constructs in leadership and decision making style of executives were not observed. Revised model has been proposed taking into account these results from analysis. The entire descriptive statistics and analysis of multiple variances were undertaken using SPSS and AMOS software tools respectively. Part of the table giving results is given below. The analysis revealed several aspects of culture, leadership style and decision making style of Indian PSE managers. Researcher 
proposes to develop new theory of decision making in organisations based on this empirical study.

Table 3: Cronbach's Alpha

\begin{tabular}{|c|c|c|c|c|c|}
\hline & $\mathbf{Z}$ & $\underset{\Xi}{\Xi}$ & 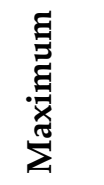 & $\sum_{\Sigma}^{\Xi}$ & 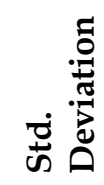 \\
\hline A Hierarchy & 235 & 8.00 & 29.00 & 19.75 & 4.25 \\
\hline B Market & 235 & 9.00 & 27.00 & 18.95 & 3.86 \\
\hline C Clan & 235 & 9.00 & 30.00 & 19.93 & 3.99 \\
\hline D Adhocracy & 235 & 9.00 & 29.00 & 20.94 & 3.85 \\
\hline Organisational culture & 235 & 9.50 & 27.00 & 19.89 & 3.51 \\
\hline
\end{tabular}

Table 4: Organisational culture Descriptive Statistics

\begin{tabular}{|l|c|c|}
\hline & Cronbach's Alpha & N of Items \\
\hline $\begin{array}{l}\text { Organisational } \\
\text { culture }\end{array}$ & & \\
\hline Hierarchy & 0.679 & 6 \\
\hline Market & 0.733 & 6 \\
\hline Clan & 0.712 & 6 \\
\hline Adhocracy & 0.786 & 6 \\
\hline
\end{tabular}

- Hierarchy: Its components have acceptable internal consistency (considering the thumb rule of $0.6 \leq a<0.7$ and a Cronbach's alpha value of 0.679 ).

- Market: Its components have acceptable internal consistency (considering the thumb rule of $0.7 \leq a<0.9$ and a Cronbach's alpha value of 0.733 ).

- Clan: Its components have acceptable internal consistency (considering the thumb rule of $0.7 \leq a<0.9$ and $a$ Cronbach's alpha value of 0.712).

- Adhocracy: Its components have acceptable internal consistency (considering the thumb rule of $0.7 \leq a<0.9$ and a Cronbach's alpha value of 0.786 ). 
The"Organisational Culture Assessment Instrument" (OCAI) is considered as a validated research method to examine organisational culture of any organisation. The model is based on the Competing Values Framework. In this framework there are four Competing Values and each one corresponds to one of the four types of organisational culture. According to the instrument developers and subsequent application of tool in more than 10,000 companies, as handle for change management within organisations, it was confirmed that every organisation has unique mix of these four types of organisational culture. Hence, the instrument used would facilitate discovery of mix of four types of described organisational cultures and high Cronbach's Alpha values.

SEM Model: Three structural equation models were developed and tested for fitness and causality. Here one model is presented. To test the theoretical models, structural equation modeling (SEM) is used as per the guidelines of SEM literature provided by Brown and Kline (2005). The goal of using the SEM analysis is to determine the extent to which the theoretical model is supported by study sample and collected sample data. It followed 5 building blocks. Among the following only three aspects are briefly highlighted here.

1. Model Specification

2. Model Identification

3. Model Estimation

Model Specification, as a pathdiagram
4. Model Testing

5. Model Modification

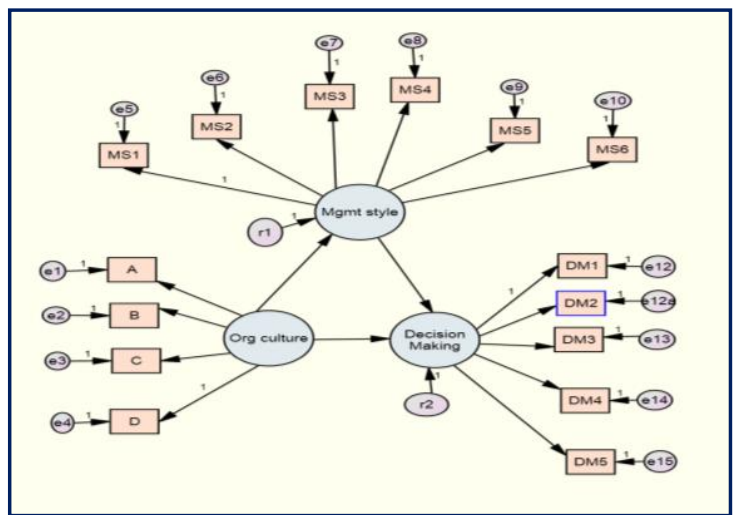

Exhibit: Model 1. 
Table 5.Model Identification-empirically both the structural and the measurement models

\begin{tabular}{|c|c|c|c|c|c|c|}
\hline $\begin{array}{l}\overline{0} \\
\text { ¿ } \\
\Sigma\end{array}$ & 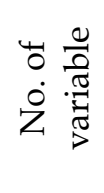 & 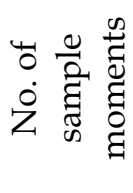 & 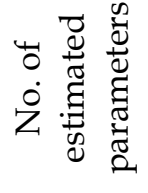 & 告 & 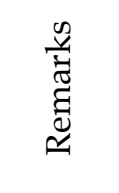 & $\begin{array}{l}\overline{0} \\
\frac{0}{0} \\
\Sigma\end{array}$ \\
\hline OC_MS_DC & 14 & 105 & 35 & 70 & $\mathrm{DF}>0$ & $\begin{array}{c}\text { Over } \\
\text { Identified }\end{array}$ \\
\hline
\end{tabular}

Here Model Fit is seen as the ability of, as indicated above, an overidentified model to reproduce the correlation or covariance matrix of the variables and is the first step towards Structural Equation Modeling. Worthington \& Whittaker (2006) suggest factor loadings of greater than 0 . Final model has elements with more than 0.5 loading, however all elements showed significant loading in the test models. Researchers suggest that any empirically underidentified parameters are very unstable, may be due to high correlation between any of the causal variables i.e., existence of multi-collinearity of variables.

Table 6.Model Testing-parameters are statistically estimated from data(AMOS)

\begin{tabular}{|l|c|l|}
\hline \multicolumn{1}{|c|}{ Parameter } & $\begin{array}{c}\text { Observed } \\
\text { Value }\end{array}$ & \multicolumn{1}{c|}{$\begin{array}{c}\text { Recommended } \\
\text { Value }\end{array}$} \\
\hline CMIN/DF & 2.409 & $<5$ \\
\hline GFI & 0.908 & $>0.9$ (Hooper et al, 2008) \\
\hline CFI & 0.947 & $>0.9$ (Hooper et al, 2008) \\
\hline TLI & 0.932 & $>0.9$ (Hooper et al, 2008) \\
\hline RMSEA & 0.078 & $\begin{array}{l}.08 \text { to } 1.0 \\
\text { (MacCallum et al, 1996). }\end{array}$ \\
\hline RMR & & .08 to 1.0 (MacCallum et al) \\
\hline SRMR & 0.069 & .08 to 1.0 (MacCallum et al) \\
\hline Chi Square (d.f) & 0.059 & \\
\hline
\end{tabular}

MODEL FIT: This part model was tested for fitness. The estimated parameters have been explained to predict the correlations or covariance between endogenous variable. The fit of this model is 
demonstration of researchers approach and it is possible that when complex multidimensional model is developed using all constructs and if this part model fitness is poor with reference to the final model, it will be re-specified or certain latent constructs will be knocked off to develop alternate model. Following statistical parameters of themodel1 as measured by AMOS are briefly explained.

AMOS lists relative chi-square as CMIN/DF (the chi-square fit /degree of freedom), is index, also called normal chi-square. CMIN - minimum value of the discrepancy between the model and the data and is the same as the chi-square statistic. CMIN/DF is an index of how much the fit of data to model has been reduced by dropping one or more hypothesized paths. Analysis is an attempt to make it less dependent on sample size. Acceptable ratio values should be in the range of $2 / 1$ or $3 / 1$ indicates fit between the hypothetical model and the sample data (Carmnines \& McIver, 1981). Several researchers have recommended using ratios as low as 2 or as high as 5 to indicate a reasonable postulated model fit (Marsh \& Hocevar, 1985).The researcher's model is just-identified and the good fit was found and is acceptable. The GFI [Goodness of Fit Index] is similar to the Baseline Comparisons. Generally its value is between 0 and 1 , with 1 indicating perfect fit. The model is close to perfect fit. Some use the AGFI [Adjusted Goodness of Fit Index] and another similar measure is PGFI [Parsimony Goodness of Fit Index] both of which depends on degrees of freedom available for testing the model, its values should be below zero. Tucker Lewis Index (TLI) greater than or equal to 0.9 indicates acceptable model fit and the study model meets this requirement. RMR [Root Mean Square Residual]: The smaller the RMR the better, with $R M R=0$ indicating a perfect fit. This model has acceptable fit as the measure of the square root of the average squared amount by which this model's estimated sample variances and covariances differ from their actual values in the data. SRMR (Standardized Root Mean Square Residual): The smaller the SRMR, the better the model fit. SRMR $=0$ indicates perfect fit. A value less than 0.08 is considered good fit. The identified model is a good fit.CFI (Comparative Fit Index)is incremental measure, it's value close to 1 indicates a very good fit, $>0.9$ or close to 0.95 indicates good fit, by convention. CFI should be equal to or greater than .90 
to accept the model. CFI is independent of sample size. CFI is recommended for routine use. Gerbing and Anderson (1993) recommended RNI and CFI measure. Study model is good fit. Some researchers suggest use of CFI or TLI as they are considered to be highly correlated. Also it is estimated that the TLI and CFI do not vary much with sample size, even larger samples have less variation. The RMSEA is at present the most common measure of model fit and it is reported in almost in all research works involving CFA or SEM. Different researchers have prescribed acceptable values for model fit. For example MacCallum, Browne and Sugawara (1996) suggest that a value of 0.01 indicates excellent fit, value of 0.05 as good fit and a value of 0.08 as mediocre fit. However, others have suggested RMSEA value of 0.10 as the cutoff for poor fitting models. Some others suggest RMSEA values of 05 or less are good fit, $<0.1$ to $>0.05$ are moderate, and 0.1 or greater are unacceptable. RMSEA $=.00$ indicates perfect fit. Study model has an acceptable fit.

Conclusion: The hypothesized model OC_MS_DC indicates that there is relationship between organisational culture and decision making construct through mediating construct Management Style. Individual hypothesis between these latent constructs have been developed and is tested separately. The study is expected to bring about divergent view to organisational theory about culture and decision making.

\section{References:}

Ali, A., \& Patnaik, B. (2014). Influence of organisational climate and organisational culture on managerial effectiveness: An inquisitive study. The Carrington Rand Journal of Social Sciences, $1(2), 1-20$.

Blenko, M., Mankins, M., \& Rogers, P. (2011). Shaping your company's decision style. Retrieved July 13, 2011, from Forbes: http:/ / www.bain.com/publications/articles/shaping-yourcompanys-decision-style-forbes.aspx,(c) 1996-2014. Bain \& Company.

Boomsma, A. (1983). On the robustness of LISREL (maximum likelihood estimation against small sample size and non-normality. 
Amsterdam: Socio-metric Research Foundation. (Doctoral dissertation, University of Groningen, The Netherlands).

Cameron, K. S., \& Ettington, D. R. (1988). The conceptual foundations of organisational culture. Higher Education: Handbook of Theory and Research, 356-396. New York: Agathon.

Cameron, K. S., \& Quinn, R. E. (1999). Diagnosing and changing organisational culture. Addison: Wesley Publishing.

Cronbach, L., (1990). Essentials of psychological testing. New York: Harper \& Row.

Dane, E., \& Pratt, M. G. (2007). Exploring intuition and its role in managerial decision making, Academy of Management Review, 32(1).

Denison, D. R. (1990). Corporate culture and organisational effectiveness. New York: Wiley.

Elangovan, A., \& Jayashree, J. M. (2013). A study on organisational culture with reference to sail. Salem International Journal of Social Science EInterdisciplinary Research, 2(6), 33-54.

Garver, M. S., \& Mentzer, J. T. (1999). Logistics research methods: employing structural equation modelling to test for construct validity. Journal of Business Logistics, 20(1), 33-57.

Gerbing, D. W. \& Anderson, J. C. (1988). An updated paradigm for scale development incorporating uni-dimensionality and its assessment. Journal of Marketing Research, 25 (May), 186-192.

Gorsuch, R. L. (2003). Factor analysis, in Schinka J. A \& Velicer W. F. (Eds.), Handbook of psychology: Research methods in psychology, 143-164. Hoboken, NJ: John Wiley.

Graves, D. (1986). Corporate culture - diagnosis and change: Auditing and changing the culture of organisations. Frances Pinter Publishers.

Handy, C. (1993).Understanding Organisations (4th ed). London: Penguin Books.

Handy, C. (1995). Gods of Management: The changing work of organisations ( $4^{\text {thed }}$ ). London: Arrow Books.

Handy, C.B. (1990). Understanding organisations (3 ${ }^{\text {rd }}$ ed.). Harmondsworth: Penguin Books.

Harrison, (1972, May-June). Understanding your organisation's Character. Harvard Business Review, 119-28.

Harrison, R. (1993). Diagnosing organisational culture. Pfeiffer: Trainer's Manual. 
Harrison, R., \& Stokes, H. (1992).Diagnosing organisational culture. Amsterdam: Pfeiffer.

Hoelter, D. R. (1983). The analysis of covariance structures: Goodness-of-fit indices. Sociological Methods and Research, 11, 325-344.

Hofstede, G. (1991). Cultures and organisations- Software of the mind: Intercultural cooperation and its importance for survival. London: Harper Collins Publishers.

Jepsen, D.A., \& Dilley, J. S. (1974). Vocational decision-making models: A review and analysis. Review of Educational Research, 44(3), 331-349.

Jossy M., (2007).The relationship of organisational culture with productivity and quality: A study of Indian software organisations, Employee Relations, 29(6). 677 - 69.

Kline, R. B. (2005). Principles and practice of structural equation modeling (2nd ed.). New York: Guilford

Levin, K. A. (2006). Study design III: Cross-sectional studies. Evidence-based dentistry, 7, 24-25. doi:10.1038/sj.ebd.6400375.

MacCallum, R. C., Browne, M. W., \& Sugawara, H. M. (1996). Power analysis and determination of sample size for covariance structure modeling. Psychological Methods, 1(2), 130-149.

Malhotra, N. K. (2010). Marketing research: An applied orientation (6 $6^{\text {th }}$ ed.). New Jersey: Pearson Prentice Hall.

McCarthy, E. (1998). The dynamics of culture, organisational culture and change. AI \& Society, 12(3), 155-184. doi: 10.1007/BF01206194.

McGivern, Y. (2006). The Practice of Market and Social Research: An introduction (2nd ed.). Haralow: Pearson Education Limited.

McNamara, C. (2000). Organisational culture. Free Management Library. Retrieved from www.managementhelp.org/ org_thry/ culture/culture.htm

Messner, W. (2013). Effect of organisational culture on employee commitment in the Indian IT services sourcing industry. Journal of Indian Business Research, 5(2), 76 - 100.

Ouchi. W. G., \& Wilkins, A. L. (1985).Organisational culture. Annual Review of Sociology. 11, 457-483.

Quinn, R. E. (1988). Beyond rational management: Mastering paradoxes and competing demands of high effectiveness. San Francisco: JosseyBass. 
Parker, M. (2000). Organisational culture and identity unity and division at work, University of Leicester, UK: Sage Publications Ltd.

Sanjeev, K. S., \& Sharma, A. (2010, January). Examining the relationship between organisational culture and leadership styles. Journal of the Indian Academy of Applied Psychology, 36(1), 97-105.

Schein, E. H. (1990, February). Organisational culture, American Psychologist. 45, 109-119.

Schneider, B. (1990). Organisational climate and culture. San Francisco: Jossey Bass.

Schneider, W. E. (2000). Why good management ideas fail: The neglected power of organisational culture. Strategy $\mathcal{E}$ Leadership, 28(1), $24-29$.

Scott, S. G., \& Bruce, R. A. (1995). Decision-making style: The development and assessment of a new measure. Educational and Psychological Measurement, 55 (5), 818-831.

Sing, A. K. (2001). A study of HRM practices and organisational culture in selected private sector organisations in India. AOP, 18(4).

Sivo, S. A., Fan, X. T., Witta, E .L., \& Willse, J. T. (2006). The search for 'Optimal' cutoff properties: Fit index criteria in structural equation modeling. The Journal of Experimental Education, 74(3), 267-289.

Thompson, B. (2004). Exploratory and confirmatory factor analysis: understanding concepts and applications. Washington, DC: American Psychological Association.

Trompenaars, F., Hampden-Turner, C. (2013). Riding the Waves Culture : Understanding Cultural Diversity in Business. EBSCO Publishing: eBook Academic Collection (EBSCOhost) - printed on 9/10/2013 4:05 AM via YASAR UNIVERSITESI KUTUPHANESI. London: Nicholas Brealey Publishing.

Velicer,W. F., \& Fava, J. L. (1998). Effects of variable and subject sampling on factor pattern recovery. Psychological Methods, 3(2), 231-251.

Worthington, R. L. \& Whittaker, T. A. (2006). Scale development research: A content analysis and recommendations for best practices. The Counselling Psychologist, 34(6), 806-838. 